\title{
The Effectiveness of Team Teaching in Improving Students' Reading Skills
}

\author{
Rosnani Sahardin ${ }^{1 *}$, Mirza Adia Nova ${ }^{2}$ \\ ${ }^{1}$ Senior English Lecturer, Syiah Kuala University, Banda Aceh, Indonesia \\ ${ }^{2}$ Assistant to Rosnani Sahardi, Syiah Kuala University, Banda Aceh, Indonesia
}

*Corresponding Author: Rosnani Sahardin, Senior English Lecturer, Syiah Kuala University, Banda Aceh. Indonesia

\begin{abstract}
It is assumed that teacher quality plays a significant role in determining the effectiveness of a learning program. This study intends to analyze the effectiveness of the English teachers at the SD Teuku Nyak Arif Bilingual School at Lamnyong, Banda Aceh, through their implementation of Team Teaching in two skills involved in reading which are vocabulary and details in the reading. Data were collected through observation of teachers in their teaching programs and through a reading test given to the students toward the end of the observation. The test results revealed a mean score of 85.7. Compared to a score of 75, which is the national standard mean score for English determined by the National Authority of Education in the country, the students' mean score is considered very well.
\end{abstract}

Keywords: team teaching, reading, English teacher, reading test

\section{INTRODUCTION}

Every method of teaching has its strengths and weaknesses. Employing the proper techniques and methods for a certain need in the classroom provides excellent results for the students. In the learning process, many methods can be employed to engage students and peak their interest. But, teachers need to be creative and innovative in looking for methods that encourage students to be active, creative, and to have fun in achieving the learning objectives of the curriculum. Buckley (1999) suggests that if the learning process and methods are not adequate, the school will encounter issues when teaching the students how to understand a text. Based on interviews with teachers during a preliminary study at the Nyak Arif Bilingual Elementary School (SDNA), many students found it difficult to understand certain words or phrases they encountered in the classroom. This is one among other reasons for Buckley (1999) to suggest turning to the implementation of Team Teaching. According to Karin Goetz (2000), Team Teaching is an efficient and fun method in learning process, particularly, in improving reading skills.

Researchers of Team Teaching have addressed a number of models and variations of the practice. Soewalni (2007), for instance, describes three variations of Team Teaching based on the divisions of tasks of the participating teachers. Goetz (2000) indicates that in Traditional Team Teaching, teachers actively share the instructional materials and skills among all students. The primary teacher may present a topic on word formation and meaning using inflections while another partner will quiz their students until they understand the new word. For example, the word read may become reading, reader, readable, readability, unreadable, un-readability, etc.

While Team Teaching on the topic of reading skills can include many related skills, the present study focuses on word meanings (vocabulary) and detail. There has not been any previous publication where Team Teaching was implemented in English language classroom. The research was conducted at SDNA Bilingual School at Lamnyong, Banda Aceh, where Team Teaching Methods have just recently been implemented. It is expected that this study will reveal the effectiveness of Team Teaching in increasing students' reading skills. In order for the program to be successful, teachers must be able to identify challenges the students face in their effort to understand text. This research may also become a reference study for lecturers and students who intend either to teach or further study reading skills. 


\section{LITERATURE REVIEW}

\subsection{Team Teaching}

Team Teaching is defined as a group of two or more teachers cooperate and elaborate their teaching steps from planning, conducting and evaluating lessons for same group of students (Beggs, 1964:7). Through the method, teachers are expected to work together in teaching and solving together any problems they may face. Buckley (1999:5) asserts that Team Teaching requires all members of the teaching team to attend several or all of the class sessions to observe, interact, question, and learn. They must also meet regularly set goals and strategies for their class. Each teacher with a special competency has an opportunity to present materials that he/she has prepared. For many researchers, including Beggs (1964), Team Teaching is understood as important for the acceleration of the intellectual enlightenment of the students' ability, emotion, and spirit. Team teaching allows students to be experts in management and leadership with a humanistic, psychological, and social approach because the concept of team teaching requires teachers who are competence in the matters being discussed and complete material.

Team Teaching is always done by two teachers together. A teacher acts as either a presenter or informer, while the other acts as a guide in discussion groups or at the individual level. The team members alternatively present the materials. Discussion is guided together. Last, a senior teacher presents the steps in training, observation, practice and information as needed. Class is divided into two groups. Each group is guided by a teacher. At the end of the lesson each group presents a report and responds to questions and calculates together.

Traditionally, Team Teaching is a method in which two teachers teach in the same class with the same items at the same time. In general, it follows the following principles.

There are two teachers in the classroom. There is the primary teacher who teaches in partnership with the other teacher. The teachers work together in the teaching process and complement the abilities or fill in the deficiencies of the other. They work as a team.

Team members take turns to present the lessons. Guided discussions are done together and complement students' answers. However, the primary teacher plays the leading role in teaching the lesson.

Teachers will delegate problem solving to improve student's achievement For example, if the students have difficulty understanding the meaning of a word, the partner teacher will handle it.

The teacher and partner understand the material and the learning content to be taught. The teachers in the team do not only need to know the theme of the material to be delivered to the students, but also both of them must know and understand the contents of the subject matter. They complement the other's lack of knowledge. The benefits of this dynamic can be felt in the delivery of content to the students and in answering the students' questions regarding the teachers' explanations.

In Team Teaching, the division of roles and responsibilities of each teacher should be clearly discussed so the teachers know the roles and duties of each other in the classroom.

\subsection{Types of Team Teaching}

The kinds of Team Teaching regarded to the setting are two, i.e. Semi-Team Teaching and Full Team Teaching. According to Soewalni (2007), they vary in the implementation. In Semi-Team Teaching, teachers teach the same subjects in different classes with materials and methods they have agreed on. After that, the same subject is presented by the teacher in turns according to the subject.

Full Team Teaching is implemented together by the teachers. One teacher acts as a presenter and the other guides discussion in groups. Then, the team member alternatively presents the materials and guides discussion together. Last, a senior teacher presents the steps of learning, observation, or practice as necessary. The class is divided into two groups; each group is guided by a teacher. At the end of the lesson, each group presents a report, provides feedbacks and draws conclusions together.

\subsection{Styles of Team Teaching}

There are some styles in collaborative teaching. First is collaborative teaching. It is the conventional form of team teaching as Rottier (2001) stated that this type of teaching allows two teachers to design 
the plan and deliver the subjects together in class while discussing it. This style makes two teachers look like panel teaching when implementing lesson plans. Laal et. al (2014) emphasize the importance incollaborative style that collaborative learning is happening where teachers are more like facilitators and students work their best in constructing the lessons designed by the teacher. Next is complimentary or supported instruction where it works out more like the usual teaching with one teacher being the helper in the class (Villa, n.d). Though this type of team teaching seem to be simple, the other teacher who works as helper can actually control the learning process and assists the students who need help. Then parallel instruction where two groups are taught in the same class each by different teacher (Rottier, 2001). Every teacher who facilitates the teaching will have more time to check each student understanding individually. Later is differentiated split class where learners are grouped into two or more which suitable with the learning objectives but different sub categories of learning objectives (Rottier, 2011). In this type of team teaching teachers are challenged to deliver the same big picture of the lesson but choosing which group to learn, and which group to review. Last is monitoring teacher where one teacher teaches and the other is more like a supervisor which control the learning process (Rottier, 2001).

\subsection{Models of Team Teaching}

This research focused on two models in team teaching, i.e. supported instructional teacher and monitoring teacher. Supported instruction is defined as a model where "One teacher is responsible for teaching the content to the students while the other teacher takes charge of providing follow-up activities on related topics or on study skills" (Goetz, 2000). Monitoring teacher on the other hand is where one teacher assumes the responsibility for delivering instruction to an entire class while the other teacher circulating the room, watching and monitoring students' understanding and behavior (Goetz, 2000).

\subsection{The Effectiveness of Team Teaching}

Most works and authors reviewed here believe that the Team Teaching methodology in the subject of English language is highly effective if it is done adequately based on the procedures recommended by experts (Goetz, 2000). One of the studies was conducted by Schwarzer, Kahn, and Smart (2000) related to the teachers and students' activities and factors influencing students' output in reading class using Team Teaching method. The research was conducted at the University of Texas at Austin applying team teaching to all of the skills of reading. The result of this research shows that students learned effectively, and independent students found the purpose of their learning and thus appreciated their progress in learning.

\subsection{Teaching Reading Skills}

In teaching reading, a teacher should be able to help the students understand the information in the text. In this case, teacher should also be able to help students learn the information easily. Teaching reading involves teaching word recognition, intellect, and emotion interrelated with prior knowledge to understand the message communicated (Goodman, 1976; Smith, 1982). Because teaching is a process, when teaching is most successful, both students and teacher learn. If little or no learning takes places, the teaching has been unsuccessful. Team teaching is not the only answer to all problems plaguing teachers and administration. As Buckley mention that team teaching “.....requires planning, skilled management, willingness to risk change even failure, humility and open-mindedness, imagination and creativity"(p. ?).

\section{Methodology}

This study used a descriptive, qualitative research method to examine both the process and the effectiveness of Team Teaching. The method was adopted by Fraenkel and Wallen (1993). Descriptive qualitative research is concerned with providing descriptions of phenomenon that occur naturally, without the experiment or an artificial treatment (Best \& Kahn, 1993:190). This research is descriptive qualitative because the writer tried to only describe the process and the effectiveness of Team Teaching to improve students' ability in understanding reading text. Some procedures were taken as follow. First, the research permission was granted by the principal of the school. Later, English teacher of grade three at the school was informed so that the research took place in the class he/she taught. 


\subsection{Location of Research}

This research was conducted at the Elementary Fatih Bilingual School (EFBS). This school is located in Banda Aceh. The researchers chose this school because this school has implemented the Team Teaching Method and the students are considered high achievers compared to other schools.

\subsection{Population and Sample}

The population of the study consists of all the 3rd grade students at EFBS. The higher grades were not included in this study since Team Teaching has not been implemented for those grades. The 3rd grade at EFBS consists of 120 students divided into three groups. Only one group of the three was included in the study since the same teacher also taught the two other groups.

\subsection{Research Instruments}

To obtain data for this study, the writers used an observation sheet and a test. The observation sheet was used to collect information regarding teachers' performances. It was designed in accordance with the procedures of Team Teaching supported instruction and monitoring teachers as suggest by Goesz (2000). The final test given to evaluate students' achievement at the end of the session was taken from Workbook MPH English 3A, a standardized and certified workbook provided by educational authority. The test consisted of 20 items with pictures and multiple-choice questions. The test includes questions related to two reading skills, i.e. vocabulary and detail information. The students were given 45 minutes to answer all the questions.

\subsection{Technique and Procedure of Data Analysis}

Following the test, the data from the test were analyzed. The writer grouped each item based on the type of question. The score for each correct answer was marked 5 or 0 where 0 was given to a wrong answer. To calculate the overall result of the test, the writer used the following formula as suggested by Sudijono (1998).

$$
\begin{array}{ll}
\mathrm{S} & =\mathrm{R} \times \mathrm{Wt} \\
\mathrm{S} & =\text { Total score } \\
\mathrm{R} & =\text { Amount of right answers } \\
\mathrm{Wt} & =\text { Score weight }
\end{array}
$$

The results of the test were classified into six categories: Excellent, Good, Fair, Poor, and Fail, which are based on Arikunto's (2006) score category criteria:

$$
\begin{aligned}
& 90-100: \text { Excellent } \\
& 85-94: \text { Very good } \\
& 75-84: \text { Good } \\
& 65-74: \text { Fair } \\
& 55-64: \text { Poor } \\
& 1-54: \text { Fail }
\end{aligned}
$$

\section{Results}

\subsection{Teacher Observations}

There were two teachers who served in one class, one acting as the primary teacher and the other serving as the partner teacher. The teachers greeted the students at the start of class to prepare them for the lesson. The primary teacher immediately took position at the front of the class, while the partner teacher moved around the students to focus their attention to the lesson. The primary teacher asked the students to take out their English text books then started the lesson by giving a short explanation of the topic of the day, "Fascinating Ocean." The teacher showed a video about planets and asked the students to name the planets in the video. Then, the teacher showed a picture of the ocean and asked some questions such as, "Why is the ocean blue?" Then, the teacher explained about the ocean. After that, the teacher asked the students to have a look in their English text book and asked the students one by one to read a passage out loud. After the students read the passage, the teacher explained each paragraph and asked the students to identify the difficult words, the adjectives, 
nouns, and verbs of the passage. Finally, the teacher began to give an exercise in order to evaluate the students' comprehension of the text.

When observed by the partner teacher, the students seemed very focused and enthusiastic about reading the text and they listened with earnest when the primary teacher explained each paragraph. The partner teacher observed the students by continually walking around the classroom and regularly stopping to observe the students' work. The teachers used a lesson plan that encouraged their students to stay active in the learning process and promoted their understanding of the reading being taught.

However, observation found that the teachers did not clearly define their roles and responsibilities regarding tasks in the classroom. They did not discuss the division of their responsibilities before or during the class. The learning methods were not compiled together; rather the primary teacher planned, taught and evaluated students without involving her partner.

The Team Teaching employed by this team meant that the students were taught by the primary teacher while the partner teacher controlled and supervised the students. The partner teacher was asked to motivate the students to encourage their activities in the learning process. The partner teacher monitored the students' activities and paid attention to the students who seemed to experience difficulty during the learning process. When the time was up, the teachers collected the students' answer sheets, and the primary teacher concluded the lesson by briefly reviewing by asking the students to identify some words in the text. The review was meant to make sure they understood the sentences or text before finally ending the lesson.

The teachers' actions did not cover all the characteristics of Team Teaching prescribed by Goetz (2000). In Team Teaching, both teachers should evaluate the materials, but in this study only the primary teacher was in charge of the material evaluation. As a result, the primary teacher taught the lesson in front of the class, she created a communicative teaching learning which involved the students in every teaching activity. However, the partner teacher only went around among students to monitor the students' behavior and their progress in the activities. The teachers treated the students based on their individual characteristics in order to make the students comfortable and help them to understand the text. The teachers also helped each other explain words that were not understood by the students. Therefore, most of the Team Teaching procedures were implemented by the teachers.

\subsection{Student Test Results}

The test was used to find out whether students understood the material delivered using the Team Teaching technique. For a detailed illustration of the data, each type of question is presented separately.

\subsubsection{Detail Questions}

There were five items to test students' abilities to grasp detail information from the text. The result is presented in Figure 1.

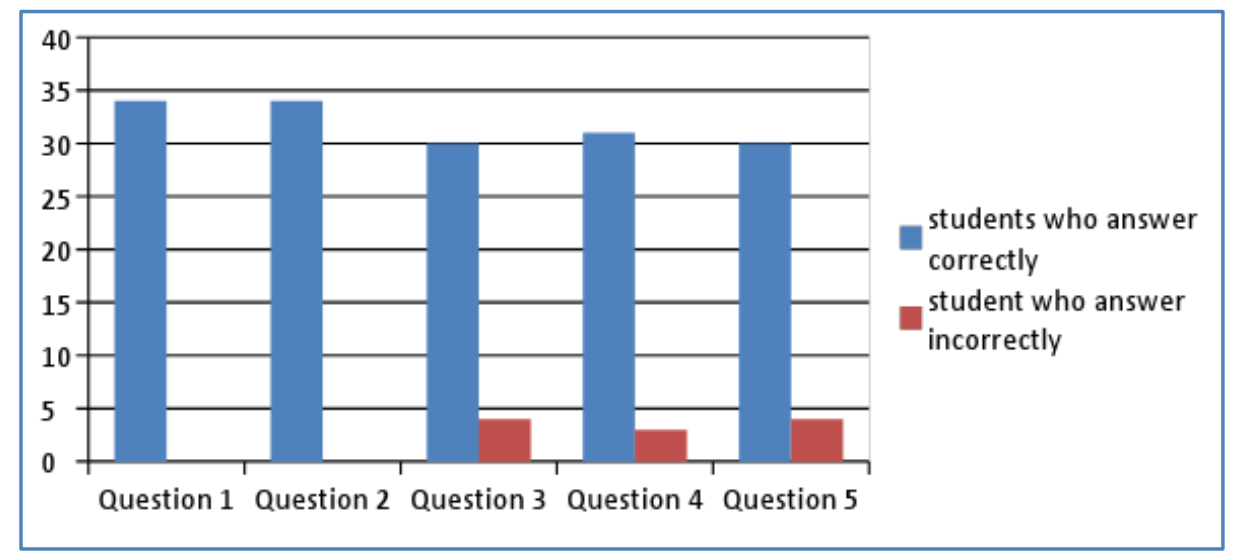

Figure1. Students' ability to answer detail questions

Figure1 shows abilities of 120 students in answering detail questions. All students could answer two of the questions correctly. For the other questions, the percent of students who failed to answer the questions correctly was less than $5 \%$. 


\subsubsection{Noun Questions}

The test results for vocabulary questions regarding nouns is presented in Figure 2, which also consists of five questions.

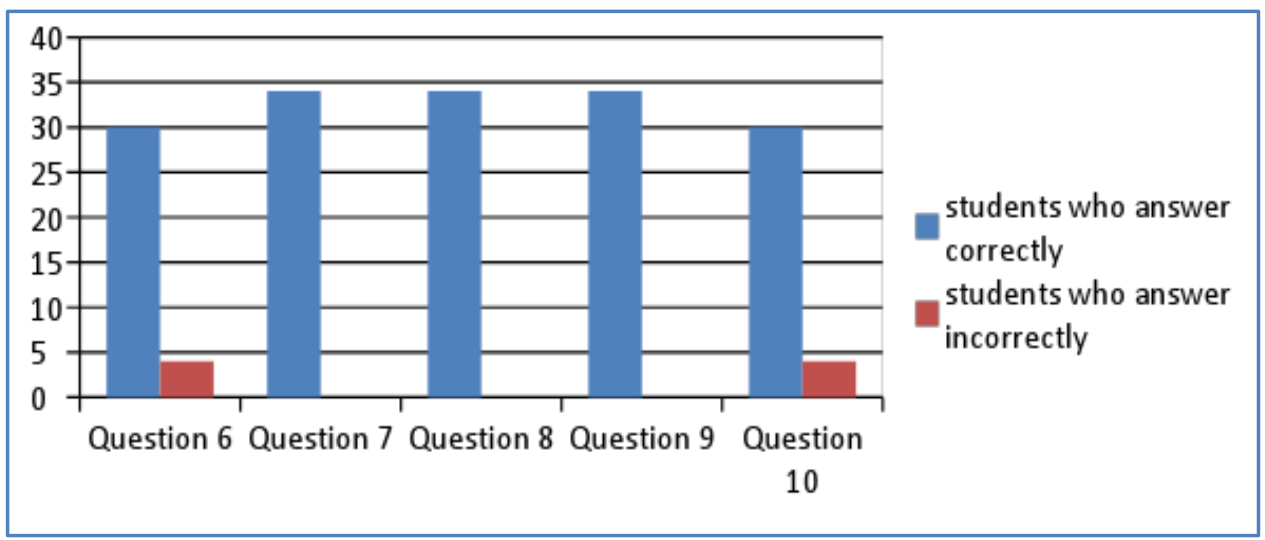

Figure2. Students' ability in answering question about nouns

Based on Figure 2, all students could answer almost all questions correctly. For questions 6 and 10, fewer than 5 students failed to answer all the questions correctly.

\subsubsection{Adjective Questions}

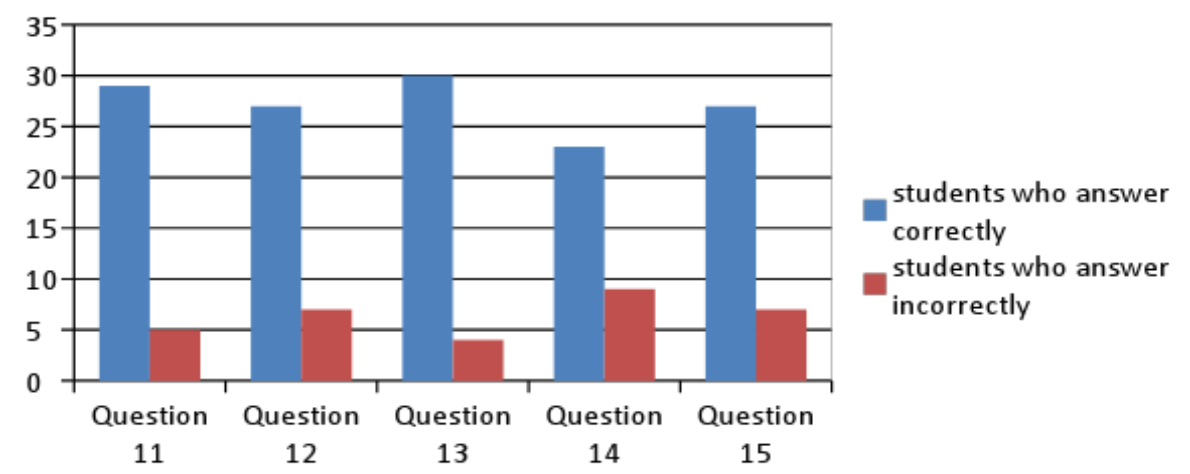

Figure3. Students' ability in answering questions about adjectives

Figure 3 shows the students' ability in answering adjective question where many students found it difficult to answer most of the questions. However, the percent of students who failed to answer all the questions was less than $10 \%$.

\subsubsection{Verb Question}

The last vocabulary type tested was about verbs, which also consisted of five questions. The result is presented in Figure 4.

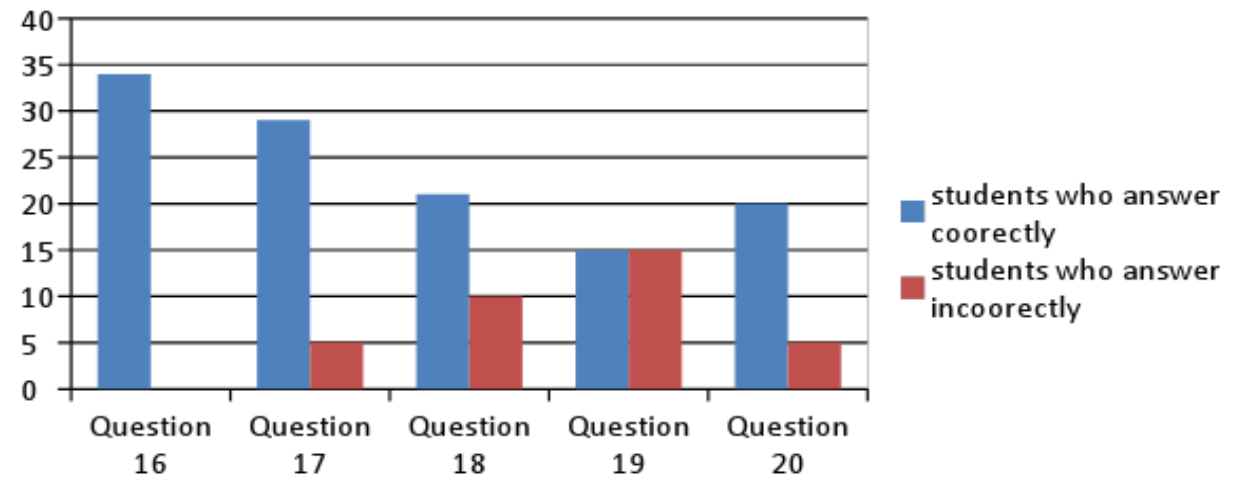

Figure4. Students' abilities in answering question about verbs

Figure 4 shows that there were many students who could not answer questions 18, 19, and 20. 


\subsubsection{Detail and Vocabulary Mastery}

The total achievement percentage of students in answering questions about detail information and vocabulary (noun, adjective, and verb) questions is summarized in Figure 5 below.

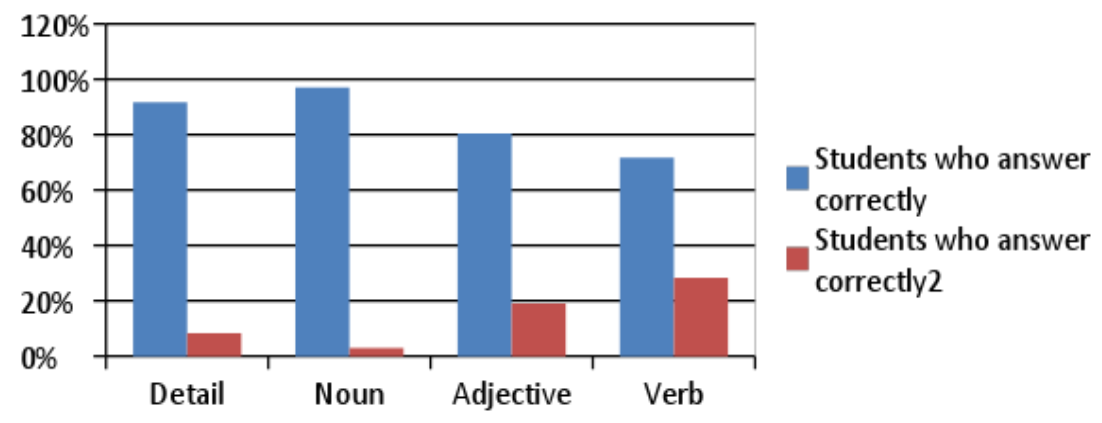

Figure5. The results of achievement test

Figure 5 show that $92 \%$ of students could answer questions about the detail information correctly. For the noun questions, $97 \%$ of the students answered correctly, $80.5 \%$ answered correctly for adjectives and $71 \%$ for verbs. The figure suggests that vocabulary questions are more difficult compared to detail information questions. For vocabulary lesson, verbs and adjectives are more problematic compared to nouns.

In addition, for a better picture of student's level of achievement, the scores are presented in range of standard scores suggested by Arikunto (2005).

Table1. The criteria of standard score of students' achievement

\begin{tabular}{|l|l|l|l|}
\hline \multirow{2}{*}{ Ranges } & \multirow{2}{*}{ Classification } & \multicolumn{2}{c|}{ Result } \\
\cline { 3 - 4 } \multicolumn{1}{c|}{ Frequency } & \multicolumn{1}{c|}{ Percentage (\%) } \\
\hline $95-100$ & Excellent & 11 & $32.4 \%$ \\
\hline $85-94$ & Very Good & 11 & $32.4 \%$ \\
\hline $75-84$ & Good & 8 & $23.5 \%$ \\
\hline $65-74$ & Fair & 4 & $11.8 \%$ \\
\hline $55-64$ & Poor & - & - \\
\hline $0-54$ & Fail & - & - \\
\hline
\end{tabular}

The table above shows that the scores lie in the 95 - 100 range, which is categorized as "excellent," and there are eleven students (32.4\%) who reached this category. The range of scores that lie in $85-$ 94 are classified as "very good," which includes 11 students (32.4\%). Next, the scores in the $75-84$ range is categorized as "good," which includes 8 students $(23.5 \%)$. The final 4 students $(11.8 \%)$ obtained scores in the $65-74$ range, which is categorized as "fair." The mean score of the students in the 3rd grade at Teuku Nyak Arief Fatih Bilingual Elementary School was 85.7. That score indicates that the students' achievement in comprehending the reading aspect of information detail and vocabulary can be classified in the "very good" category as presented in the table above. Therefore, it can be concluded that the student' ability in understanding detail information and mastering vocabulary is very good although there were three students who still need further instruction.

\section{CONCLUSiONS}

This study report is purely based on observational data of the activities of teachers while they were teaching reading using Team Teaching procedures as suggested by experts in the field. In addition, the researchers administered a test to evaluate students' achievements after they were taught reading by using Team Teaching technique.

The result of observation shows that the English teachers at this Elementary Bilingual School have indeed adopted a Team Teaching methodology as their main strategical procedures in teaching English in accordance with almost all procedures advocated by Goetz (2000). The students of the team-taught class had a mean score of 85.7, which is more than 10 points above the national mean score. Moreover, some students did not know the meaning of some verbs because they are rarely used in texts, especially for question number 19 , where only half of the students could answer the question correctly. 
However, further studies about this teaching procedure at this and other schools are necessary to fully evaluate the effectiveness of the teaching method. Universities are also recommended to improve its English education by adopting Team Teaching procedures as suggested by language teaching experts.

\section{REFERENCES}

[1] Arikunto, S. 2005. Dasar-Dasar Evalusi Pendidikan (EdisiRevisi) [The Principles of Education Evaluation-Revision Edition. Jakarta: P.T.Bima Aksara.

[2] 2006. Prosedur Penelitian; Suatu Pendekatan Praktik [Research Procedures; A Practical Approach].Jakarta :Rineka Cipta.

[3] Barbara D, Stood. 1981. Reading Instruction.Boston: Houghton Miffin Company.

[4] Barchers, Suzanna. 1998. Teaching Reading: From Process to Practice. London: Wadsworth Publishing Company.

[5] Best, W.J and Kanh, J.V. 1993.Research in Education. Boston :Allyn and Bacon

[6] Buckley, Francis. J. 1999. Team Teaching: What, Why, and How? Thousand Oaks, CA : Sage

[7] Goetz, Karin. 2000. Perspectives on Team Teaching. From: http://people.ucalgary.ca/-egallery/goetz.html, accessed on December 2, 2010.

[8] Heilman, A.W. 1981. Principle and Practice of Teaching Reading. Ohio: Charles E. Merril Publishing Company.

[9] Johnson, E.B. 2002.Contextual Teaching and Learning. California: Corwin Press.

[10] Laal, M., Khattami-Kermanshashi, Z., and Laal, M. 2014.Teaching and education; collaborative style. Procedia- Social and Behavioral Sciences 116(2014) 4057 - 4061

[11] MC. Cormack, Rachel. L, and Susan Lee. 2010. Teaching Reading: Strategy and Resource for Grades K6. New York: The Guiford Press.

[12] Purwadarminta.1994. Kamus Besar Bahasa Indonesia [Dictionary of Indonesian Language].Jakarta :Balai Pustaka.

[13] Rottier, J. 2001.Team Teaching. National Middle School Association 2001.

[14] Said, A. 1981.ManajemenSistem Informasi [Management of Information System]. Jakarta: Erlangga.

[15] Smith, Brenda D. 1995. Breaking through. College reading Fourth Edition. United States of America: Harper Collins.

[16] Soewalni, S. 2007. Team Teaching. The paper of Applied Training Program 2007 in education development Center UNAS. (Online). http.//www.google.com//team teaching/akhmadsudrajat: let's talk about education. Html, accessedon October 10, 2011

[17] Stauffer, Russel G. 1986. Directing Reading Mastery as a cognitive process. New York: Harper and Row Published.

[18] Sudijono. 2007. Statistika Untuk Penelitian [Statistics for Research]. Bandung: Alfabeta.

\section{AUTHOR's BIOGRAPHY}

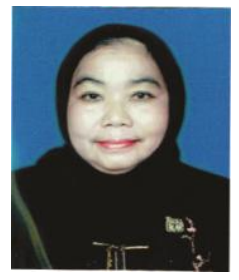

Ms. Rosnani Saharsi, Mpd., is now a Senior Lecturer at the English Department of the FKIP, Syiah Kuala Universty, Banda Aceh, Indonesia. She is graduated from the same Department in 1986. She has been Research and Lecturer Assistant to Prof. Dr, Bahrein T, Sugihen, MA. (ret.) since 1987 - 2006. She earned her Mpd degree in 2010. In 1992, The international visiting program in united state invited by cultural affair us ambassy in 2000. In the following year she was again sent to do research at the American Studies Program Research Center in Hyderabad, India. Prior to those activities show a scholarship to English for Special Purposes at RELC, Singapore. She has also been lately published in International Periodicals and the year she was also invited to USA for international visiting program for 1 month. She also joined international seminar in malaysia, singapore and also penang and bangkok.

Citation: Rosnani Sahardin, MirzaAdia Nova. "The Effectiveness of Team Teaching in Improving Students' Reading Skills". International Journal on Studies in English Language and Literature (IJSELL), vol 6, no. 11, 2018, pp. 14-21. doi: http://dx.doi.org/10.20431/2347-3134.0611003.

Copyright: (0) 2018 Authors. This is an open-access article distributed under the terms of the Creative Commons Attribution License, which permits unrestricted use, distribution, and reproduction in any medium, provided the original author and source are credited. 